\title{
Delta Dental Of Arkansas Taking The Next Step
}

Larry R. Davis, Texas A \& M University-Texarkana, USA

Joan Brumm, Texas A \& M University-Texarkana, USA

R. Edward Bashaw, Texas A \& M University-Texarkana, USA

\begin{abstract}
Delta Dental of Arkansas, an affiliate of the Delta Dental Plans Association, had been a profitable provider of dental insurance since it's inception in 1982 as a one - product company selling group dental policies to companies in Arkansas. With the retirement of its founding CEO in 2000 after 18 years of service, its board of directors crafted a new organizational structure, hired a new CEO from the outside, restructured the board, and redirected the focus of the organization. An external marketing firm employed by the company, following extensive research, encouraged the management of Delta Dental of Arkansas' to develop a broader and more comprehensive approach to doing business. Following the consultant's recommendations, Delta Dentals' new business plan focused on ideas to generate repeat business, attract new business, diversify, and introduce additions to the company's line of services to influence company growth.
\end{abstract}

Keywords: dental insurance industry, dental associations, marketing strategy, marketing research, strategic planning, financial ratio analysis.

\section{INTRODUCTION}

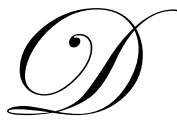

elta Dental of Arkansas (DDA) was established in Sherwood, Arkansas, a few miles north of Little Rock, in 1982 to improve oral/dental health in Arkansas and became an affiliate of the Delta Dental Plans Association, a national organization. A few days following the retirement ceremonies and social events in 2000 that honored Earl Gladden for his 18 years of service as the founding CEO of the company, the board of directors held a series of meetings to consider an expanded and refocused direction of the company.

From its inception, as limited by its charter, Delta Dental of Arkansas sold only group dental insurance policies to companies in Arkansas. It quickly attained $\$ 72$ million in annual revenue. Although appreciative of the business that was significant in covering its overhead, the board was, at the same time, concerned that $60 \%$ of DDA's business was coming from only one company. This influenced the board to identify and consider the pursuit of expanded and diversified business opportunities.

In the company's leadership transition, the board of directors, led by chairman Dr. Jim Johnston, employed Eddie Choate, a company outsider, as Mr. Gladden's replacement CEO. Phyllis Rogers was employed as Senior Vice President and Chief Financial Officer and Dr. Herman Hurd was hired as Vice President of Professional Relations.

Another significant decision was to amend the board of directors' structure which had originally consisted of 15 members, dominated by 11 dentists and four consumer members. It was changed to a ten - member body that included only four dentists and six consumer members from outside the industry. The restructuring also included an upgrading of board talents and the establishment of six board committees: the Executive Committee; the Audit, Finance, and Investment Committee; the Governance Committee; the Compensation Committee; the IT committee; and the Dental Policy Committee. 
Finally, to gain an independent and external perspective, DDA employed an external consultant to perform research about the industry and to provide recommendations for refocusing the company's business. After considering the services of several companies, Scopemark, a marketing consulting firm in Little Rock was employed for the project that included developing marketing strategies and tactics that could be transmitted to an advertising agency that was to be subsequently employed by DDA.

\section{BACKGROUND}

\section{The Delta Dental Plans Association}

In 1954, groups of dentists in California, Oregon, and Washington that wanted to increase consumer access to oral healthcare formed dental service organizations in their respective states. Led by the Washington Dental Service (WDS), they began to design dental benefits programs for organized labor unions.

In 1966, these organizations created the Delta Dental Plans Association (DDPA) to coordinate dental benefits programs for customers with employees in multiple states. The following year, WDS partnered with the International Association of Machinists to launch the first multi-state dental benefits program that began a cycle of growth and expansion for Delta Dental. To meet the needs of clients with out-of-state subscribers, WDS partnered with other Delta Dental Member Companies and Blue Cross/Blue Shield Association members to serve its clients this way through the late 1990's.

The DDPA published its commitment to expand access to oral healthcare; use its dental expertise to provide quality customer care; provide dependable service to respond to its customers' needs; and offer all the innovation, service and multi-state networks of a national carrier, but with an understanding of the unique oral health challenges and needs of individual communities. When Delta Dental of California was chosen as the dental benefits provider for the Office of the Civilian Health and Medical Program of the Uniformed Services (OCHAMPUS) program, other Delta Dental Member Companies agreed to share their provider data to centralize the administration of this large account. This resulted in the creation of the National Provider File (NPF) and in 1990, the establishment of Delta USA as the company responsible for overseeing provider data and enabling the administration of national business.

\section{Exhibit 1 \\ Delta Dental Plans Association Fast Facts}

For over 50 years, the Delta Dental Plans Association has worked to improve the oral health of Americans by emphasizing preventive care and making dental coverage affordable to a wide variety of employers, groups and individuals.

DDPA Member Companies serve over one-quarter of the estimated 165 million Americans with dental insurance, providing dental coverage to more than 50 million people in over 88,000 groups across the nation.

Delta Dental Premier offers a provider network that encompasses more than 124,000 providers in more than 182,000 office locations - the largest network in the country.

Delta Dental PPO has a national network of more than 63,000 dentists practicing in approximately 106,000 locations.

Delta Care USA has over 18,000 dentist office locations.

Delta Dental Member Companies posted approximately $\$ 13$ billion in premium revenue during FY 2006, the system's $27^{\text {th }}$ consecutive year of financial gains.

In 2006, Delta Dental Member Companies processed over 73 million dental claims or approximately 1.3 million every week, with an accuracy rate of 99 percent.

Delta Dental's unique cost control measures and contractual agreements with dentists help to ensure quality care at moderate fees, collectively saving groups over $\$ 5.3$ billion in 2006 .

Source: DDPA Publication 
Today, the Delta Dental Plans Association includes 39 independent Delta Dental member companies operating in all 50 states, the District of Columbia and Puerto Rico that provide coverage to 50 million people enrolled in over 88,000 groups. Exhibit 1 presents several association facts that the DDPS refers to as Fast Facts.

\section{Delta Dental of Arkansas}

Delta Dental of Arkansas was established in Sherwood, Arkansas, near Little Rock, in 1982 with modest means and operated in a one room office with a desk supported by three legs and a coffee can. Its charter limited the company to do business with only companies that had offices in Arkansas. In addition to that limitation, the company was started as a single product company which was subsequently determined to be a significant weakness of the company. Delta Dental of Arkansas became one of the 39 independent Delta Dental member companies that are members of the Delta Dental Plans Association.

To overcome the charter restriction, the DDA established Omega Ventures as a wholly owned subsidiary holding company licensed in 48 states that allowed expanding business to clients outside Arkansas. Also, within that scheme, Omega Administration was created as a third party administrator to administer the dental benefits plans.

Although there have been changes in building facilities, corporate offices continue to be located in Sherwood, and in its expanded structure, now administers dental coverage to more than 12 million members in approximately 2,200 employer groups. It offers benefits in Arkansas and across the nation with access to the largest network of dentists in Arkansas and the country. In 2007, Delta Dental of Arkansas had 150 employees and \$239.6 million in sales.

\section{Delta Dental of Arkansas Mission Statement}

Exhibit 2 displays the Delta Dental of Arkansas mission statement that reflects the philosophy of management that was implemented and is followed.

Exhibit 2

Delta Dental of Arkansas

Mission Statement

As the first company to specialize in dental benefits, we are passionate about oral health and its importance to future generations. Our core purpose is the advancement of oral healthcare to our customers, partners and consumers through the dental benefits programs and philanthropic efforts of our 39 independent Member Companies.

Source: Delta Dental of Arkansas Publication

\section{Competition}

In order of internally ranked significance, the major competitors of DDA are Blue Cross/Blue Shield of Arkansas, Guardian, Metropolitan Life, Ameritas, CIGNA, and Aetna

\section{Marketing Consultant Advice}

DDA employed Scopemark in 2004 to evaluate its marketing opportunities and make recommendations. Scopemarik's primary role was to assist DDA in the development of marketing strategies \& tactics that would be transitioned to a yet to be determined ad agency. The general framing recommendations were to establish rigid strategies, fluid tactics, and ignore branding and creative strategies. The tactics from the ad agency should reflect the strategies developed in the consultants' planning process.

Procedurally, Scopemark reviewed industry studies, performed competitive analysis research, performed a dental insurance market analysis, held update meetings with Lynne Lawrence, DDA's Director of Marketing, to review progress, met with Dr. Hurd, DDA Vice President of Professional Relations to attain a "dentist" perspective, and communicated with Greg Hatcher, DDA's largest producer to discuss producer perceptions of DDA. 
Exhibit 3 presents Scopemark's findings.

Exhibit 3

Scopemark's Findings

The Dental Benefits Industry was transitioning to a mature stage due to industry consolidation, focusing on repeat sales, reduction of cost, and emphasis on service (NADP).

The total dental benefits market was expected to grow $6.4 \%$ from 2003-2007 (NADP)

Arkansas ranked 7 of 10 states projected for total benefits growth (2004-2007) (NADP)

Arkansas BC/BS entered as a low price competitor.

Technological advances had not been taken advantage of by Delta Dental. (Its existing system limited technological advances.) (Scopemark Recommendation: have new system conversion in place by November, 2007)

There was a significant influx of Hispanics into the Arkansas population

Source: Scopemark Report

Exhibit 4 presents Delta Dental of Arkansas's relative location among competitors on an insurance industry positioning map.

Exhibit 4

Insurance Industry Positioning Map

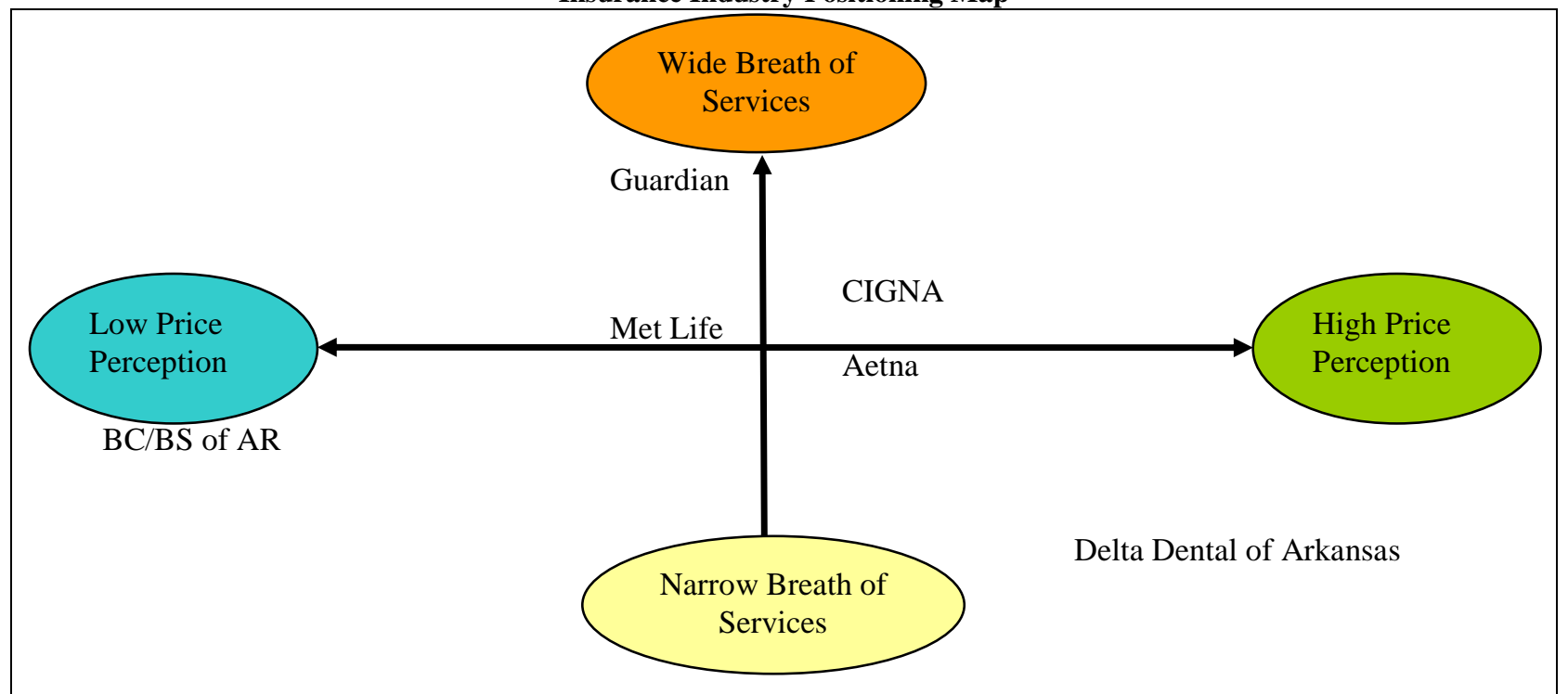

Source: Scopemark Report

Exhibit 5 presents the market wants/needs of stakeholders including enrollees, providers, employer groups, and agents, respectively, as determined by Scopemark's research.. 
Exhibit 5

Delta Dental of Arkansas

Market Wants/Needs

\begin{tabular}{|l|}
\hline Enrollees \\
\hline 1. Oral Healthcare \\
2. Richer Benefits \\
3. An Extensive Network of Service Providers \\
4. Excellent Service \\
5. Fair Premiums \\
\hline Providers \\
\hline 1. Excellent Service \\
3. Technological Advances in Service \\
\hline Employer Groups \\
\hline 1. Oral Healthcare \\
2. Richer benefits to aid in employee retention \\
3. An Extensive Network \\
4. Technological Advances \\
5. Excellent Services \\
6. Fair Premiums \\
7. Predictability \\
\hline Agents \\
\hline 1. Excellent Service \\
2. Higher Commissions \\
Source: Scopemark Report
\end{tabular}

Scopemark performed a SWOT analysis of the company and Exhibit 6 presents what the research identified as Delta Dental of Arkansas' strengths, weaknesses, opportunities and threats.

Exhibit 6

DDA Situation Assessment - SWOT Assessment

\begin{tabular}{|l|}
\hline Strengths \\
\hline 1. Organizational Efficiency \\
2. Operational Effectiveness \\
3. Long-term relationships with providers = procedural knowledge \\
4. One of the oldest carriers in the state \\
5. Largest carrier (90\% of dentists are in the Network) \\
6. Low Volatility in Pricing \\
7. $53 \%$ employers very satisfied \\
8. Market Share Leader \\
9. Low Brand Awareness of Non-Customers \\
10. DDA name suggests non-national network \\
\hline Weaknesses \\
\hline 1. Cost Structure \\
2. Technology \\
3. $50 \%$ familiarity with online eligibility maintenance \\
4. Narrow line of coverage \\
5. No money for advertising relative to nation \\
6. Deep pocket national competitors \\
7. Poor departmental \\
\hline Opportunities \\
\hline 1. 43\% of employers satisfied \\
2. 93\% of employer groups have Internet access \\
3. Receptivity of employer groups to on-line advancement \\
4. $33 \%$ of the Arkansas market is uninsured \\
5. Increasingly technology savvy market \\
6. Women make roughly $90 \%$ of all family healthcare decisions \\
7. Growing senior market \\
\hline
\end{tabular}




\begin{tabular}{l}
\hline 8. Growing Hispanic market \\
9. Weaker performers desiring narrow partner/providers \\
10. Average 41 new dentists in Arkansas over the last three years \\
11. The four target audiences want to do business with the good guys \\
12. Projected decline in uninsured (14.5\% uninsured in 2007) (NADP) \\
13. Brokers lack trust in Blue Cross/Blue Shield of Arkansas \\
\hline Threats \\
1. Ominous signs of defections from employers and dentists \\
2. Perception of high premiums \\
3. Potential dentist shortage \\
4. Blue Cross/Blue Shield of Arkansas \\
5. Guardian \\
6. Multi-line insurers capable of aggressive underwriting \\
7. Competitors paying higher commissions \\
8. Desire for one-stop shopping \\
9. Fragmentation or appearance of non-national network \\
Source: Scopemark Report
\end{tabular}

\section{Distinct Competency}

Distinct competencies are those processes and attributes of an organization creating a unique position relative to its competitors among the targeted market. This mixture should be a recipe for success that, in combination, creates a unique persona for Delta Dental of Arkansas that relevant audiences view as positive and desirable. In short, they make a company different and better.

\section{Distinct Competency Set for Delta Dental of Arkansas}

1. Operational Effectiveness

2. Long-term relationship with providers

3. Largest carrier

4. Organizational Efficiency

5. Good partner to producers

\section{Key Opportunities}

1. Receptivity of employer groups to broaden the product line

2. Weaker performers desiring narrow partners/providers

3. Growth of Hispanic market

4. $33 \%$ of market uninsured in Arkansas

5. Receptivity of employer groups to on-line advancement

\section{Sustainable Competitive Advantage}

A sustainable competitive advantage (SCA) is the organization's ability to perform in one or more ways that competitors in a given market cannot or will not match. An SCA occurs when a firm or organization matches its distinct competencies with one or more significant, relevant marketplace opportunities (key opportunities). This creates a protection from competition because the distinct competencies exercised in a particular marketplace opportunity represent barriers to competitors. Over a period of time, a sustainable competitive advantage allows an organization to most favorably reach a targeted group.

\section{THE DENTAL INSURANCE INDUSTRY}

\section{Industry Financial Data}

Delta Dental is part of the medical services industry. This industry grouping includes diverse companies within the healthcare sector serving various markets. The grouping includes clinical laboratories, hospitals, and 
health insurers. Selected financial ratios for the industry are presented in Exhibit 7. Industry data was obtained from Value Line for Delta Dental's primary SIC code number 6324. Factors affecting the profits and share prices for the health insurers within this industry include rising medical costs and enrollment.

\begin{tabular}{|c|c|c|c|c|c|c|}
\hline \multicolumn{7}{|c|}{$\begin{array}{c}\text { Exhibit } 7 \\
\text { Medical Services Industry Statistics } \\
\text { (Millions dollars) }\end{array}$} \\
\hline & $\begin{array}{c}\text { Estimated } \\
2009\end{array}$ & $\begin{array}{c}\text { Estimated } \\
2008\end{array}$ & 2007 & 2006 & 2005 & 2004 \\
\hline Revenue & 316,400 & 298,475 & 278,950 & 258,275 & 202,260 & 161,231 \\
\hline Operating Costs & 278,432 & 261,165 & 244,081 & 225,990 & 176,370 & 142,045 \\
\hline Net Profit (after tax) & 17,400 & 16,425 & 15,350 & 14,050 & 11,139 & 6,576 \\
\hline Working Capital & 8,800 & 9,400 & 10,125 & 11,050 & 19,166 & 22,223 \\
\hline Long-Term Debt & 45,650 & 43,625 & 41,225 & 38,450 & 32,023 & 24,926 \\
\hline Shareholder Equity & 102,550 & 97,075 & 91,850 & 86,875 & 82,511 & 64,177 \\
\hline
\end{tabular}

Source: Value Line March 21, 2008

Aetna is one of Delta Dental's main competitors. Aetna is a much more diversified health care benefits company than Delta Dental. Aetna offers a wide array of health insurance products and services, including medical, pharmacy, dental, behavioral health, group life, long-term care and disability plans and medical management capabilities. Notice that Aetna's working capital relative to revenue is much larger than the industry as a whole. Health insurance companies have greater short term cash needs than most companies due to medical cost reimbursement demands.

\begin{tabular}{|c|c|c|c|c|c|c|}
\hline \multicolumn{7}{|c|}{$\begin{array}{c}\text { Exhibit 8 } \\
\text { Aetna Statistics } \\
\text { (Millions dollars) }\end{array}$} \\
\hline & $\begin{array}{c}\text { Estimated } \\
2009 \\
\end{array}$ & $\begin{array}{c}\text { Estimated } \\
2008\end{array}$ & 2007 & 2006 & 2005 & 2004 \\
\hline Revenue & 34,275 & 31,350 & 27,600 & 25,146 & 22,492 & 19,904 \\
\hline Operating Costs & 29,991 & 27,588 & 24,288 & 22,305 & 19,928 & 17,854 \\
\hline Net Profit & 2,325 & 2,100 & 1,837 & 1,601 & 1,343 & 1,215 \\
\hline Working Capital & 12,825 & 12,125 & 11,500 & 11,201 & 10,618 & 12,505 \\
\hline Long-Term Debt & 2,600 & 2,550 & 2,500 & 2,442 & 1,156 & 1,610 \\
\hline Shareholder Equity & 13,875 & 11,825 & 9,975 & 9,145 & 10,105 & 9,081 \\
\hline
\end{tabular}

Source: Value Line March 21, 2008

\section{CHALLENGES GOING FORWARD}

After 18 years of stable business, the company took action to diversify and expand its business offerings. After considering the findings of the Scopemark study, the company is now sensing the opportunity to promote growth to a newer plateau by seeking currently untapped markets. In considering that, the board of directors and the management team of Delta Dental of Arkansas believed there were several questions to answer before moving forward:

- How can DDA encourage repeat business?

- How can DDA expand sales?

- $\quad$ Are there opportunities to introduce new products/services such as vision insurance?

- What is the receptivity of employer groups to broaden the product line?

- How should DDA address the significant market of uninsured in Arkansas?

- How does DDA pursue the receptivity of employer groups to on-line advancement: 
- $\quad$ Does the name, Delta Dental of Arkansas give a significant appearance of a non-national network?

- How should DDA pursue the growing market of senior citizens?

- How can DDA increase business among Hispanic consumers?

\section{Delta Dental of Arkansas: Instructor's Manual}

$\underline{\text { Intended Courses and Audience }}$

The Delta Dental of Arkansas case with its emphases on market analysis, market segmentation, and market strategy, is targeted primarily for undergraduate and graduate courses in marketing management and marketing strategy. It is also useful for courses in marketing research, entrepreneurship or small-business management, or consumer behavior.

\section{Teaching Plan}

Our suggested teaching plan covers four components of a marketing plan: (1) evaluate the current situation faced by the management of Delta Dental of Arkansas; (2) review the Strengths/Weaknesses/Opportunities/Threats (SWOT) analysis and distinct competencies presented in the case; (3) evaluate Delta Dental of Arkansas' mission statement; and (4) evaluate the need for additional market research.

\section{Delta Dental of Arkansas: Assignment Questions and Analyses}

1. In developing a situation analysis, you need to synthesize several sources of information presented in the case - such as secondary research from Value Line and primary research (in the form of both competitive analysis research and dental insurance market analysis) of Delta Dental of Arkansas customers and competition. Answer the following questions from information presented in the case:

a. What are the key market segments for Delta Dental of Arkansas? Consider segmenting the total market according to geography, demographic variables, and purchase/usage behavior.

Delta Dental of Arkansas has focused on the dental insurance segment of the medical services industry. Other possible segments are based upon demographics (gender, ethnics, and age), geography, and group type (individuals, employer, or group plans).

Most students will focus on one means of segmentation at a time when attempting to describe customers and potential customers. In this case most will recognize product type as a segment. However, combining segmentation approaches gives a more complete picture.

b. Determining the financial health of the company is an important part of a situation analysis which requires an analysis of key financial ratios in comparison with those of the industry. There are several ways to choose an 'industry' comparison. One of the most common industry measures is based on the firm's primary SIC code or Value Line's industry grouping. Another possible comparison would be with the firm's main competitors. Raw data for the Medical Services industry and Aetna, one of Delta's main competitors, was given in the case. Converting the raw data to ratios makes comparisons more meaningful.

Which would provide the most meaningful comparison for Delta Dental of Arkansas, the Medical Services industry or Aetna?

The instructor can give students the ratios or ask them to compute them. Material in the case indicates that the industry data contains diverse companies with very different operating parameters. Medical insurance providers need to maintain large amounts of liquid assets in order to meet the demand for medical cost reimbursements. Therefore, the working capital requirements for medical insurers are higher resulting in a lower turnover of working capital. 
In this case, students should recognize that comparisons with Delta Dental Arkansas' main competitors would be more meaningful when looking at ratios impacted by the unique working capital requirements of medical insurers. This case demonstrates the importance of knowing the details of the industry and the company being analyzed.

Exhibit 9

Medical Services Industry Ratios

\begin{tabular}{|c|c|c|c|c|c|c|}
\hline & $\begin{array}{c}\text { Estimated } \\
2009\end{array}$ & $\begin{array}{c}\text { Estimated } \\
2008\end{array}$ & 2007 & 2006 & 2005 & 2004 \\
\hline $\begin{array}{l}\text { Operating Margin } \\
\text { (Revenue-operating exp)/revenue } \\
\text { Net Profit Margin }\end{array}$ & $12.00 \%$ & $12.50 \%$ & $12.50 \%$ & $12.50 \%$ & $12.80 \%$ & $11.90 \%$ \\
\hline $\begin{array}{l}\text { Net profit/revenue } \\
\text { Working Capital Turnover }\end{array}$ & $5.50 \%$ & $5.50 \%$ & $5.50 \%$ & $5.44 \%$ & $5.51 \%$ & $4.08 \%$ \\
\hline $\begin{array}{l}\text { Revenue/working capital } \\
\text { Long-Term Debt/Shr Equity } \\
\text { Return on Shr Equity }\end{array}$ & $\begin{array}{l}35.95 \\
45 \%\end{array}$ & $\begin{array}{l}31.75 \\
45 \%\end{array}$ & $\begin{array}{l}27.55 \\
45 \%\end{array}$ & $\begin{array}{l}23.37 \\
44 \%\end{array}$ & $\begin{array}{l}10.55 \\
39 \%\end{array}$ & $\begin{array}{l}7.26 \\
39 \%\end{array}$ \\
\hline Net Profit/Shareholder Equity & $17 \%$ & $17 \%$ & $17 \%$ & $16 \%$ & $14 \%$ & $10 \%$ \\
\hline
\end{tabular}

Exhibit 10

Aetna Ratios

\begin{tabular}{lcccccc}
\hline & Estimated & Estimated & & & $\mathbf{2 0 0 5}$ & $\mathbf{2 0 0 4}$ \\
\hline Operating Margin & $\mathbf{2 0 0 9}$ & $\mathbf{2 0 0 8}$ & $\mathbf{2 0 0 7}$ & $\mathbf{2 0 0 6}$ & $\mathbf{2 0 0}$ & $11.40 \%$ \\
Net Profit Margin & $12.50 \%$ & $12.00 \%$ & $12.00 \%$ & $11.30 \%$ & $10.30 \%$ \\
Working Capital Turnover & $6.78 \%$ & $6.70 \%$ & $6.66 \%$ & $6.37 \%$ & $5.97 \%$ & $6.10 \%$ \\
Long-Term Debt/Shr Equity & $\mathbf{2 . 6 7}$ & $\mathbf{2 . 5 9}$ & $\mathbf{2 . 4 0}$ & $\mathbf{2 . 2 4}$ & $\mathbf{2 . 1 2}$ & $\mathbf{1 . 5 9}$ \\
Return on Shr Equity & $\mathbf{1 9 \%}$ & $\mathbf{2 2 \%}$ & $\mathbf{2 5 \%}$ & $\mathbf{2 7 \%}$ & $\mathbf{1 1 \%}$ & $\mathbf{1 8 \%}$ \\
\hline
\end{tabular}

2. Review the Strengths/Weaknesses/Opportunities/Threats (SWOT) analysis and distinct competencies presented in the case. Identify a distinct cost or differentiation competency of Delta Dental of Arkansas. How sustainable is the competency?

Students should be aware that competitors cannot easily duplicate distinctive competencies. Distinctive competencies include legally protected rights, human resources, and knowledge. The degree of difficulty in duplicating a distinct competency is an indication of how sustainable it is. In today's rapidly changing environment, maintaining and developing distinct competencies require continuous investment in resources and abilities.

3. Does Delta Dental of Arkansas' mission statement adequately describe the current and future mission of the firm? If not how would you change it?

Students should recognize that the current mission statement is too limited in its scope. It restricts the company to dental health and 39 member companies. In addition, the mission statement does not refer to quality or value of their products and services. The instructor may want to discuss the differences between DDA's mission statement with Wellpoint's.

Delta Dental of Arkansas: As the first company to specialize in dental benefits, we are passionate about oral health and its importance to future generations. Our core purpose is the advancement of oral healthcare to our customers, partners and consumers through the dental benefits programs and philanthropic efforts of our 39 independent member companies.

Wellpoints Vision: Wellpoint will transform health care and become the most valued company in our industry. Our Mission: To improve the lives of the people we serve and the health of our communities. 
4. Several possible marketing objectives are mentioned in the case including: expanding the product line, marketing to the growing Hispanic and senior citizen population, and increased utilization of Internet technology.

Discuss the need for — and affordability of — additional research before proceeding with advertising to new targeted market areas.

All students should recognize that secondary market research is much less expensive than primary market research because the costs are shared by multiple entities. However, it does not always meet the organization's needs. Primary market research is particularly well suited for research areas that the organization would not want to share with others in their industry.

Scopemark conducted primary market research into Delta Dental's current position and brand position relative to competitors. Additional research could examine consumers' views of the brand name in a different product market, buyer decision processes for the new demographic groups, and demand estimates.

If this case is used to address marketing research decisions, then students could be prompted to suggest the types of research that are most appropriate (surveys versus focus groups, samples of customers versus random samples etc.).

\section{Epilogue}

By 2008 Delta Dental of Arkansas offerings had expanded to include a variety of plans and services including: traditional fee for service, preferred provider program, dental managed care and point of service plans, customized plans and administrative service only (ASO) plans, individual coverage, and vision plans. The new interactive web site provides customers with the tools and resources needed to help manage their dental benefits.

\section{AUTHOR INFORMATION}

Dr. Larry Davis is Professor of Economics and Management at Texas A \& M University-Texarkana. He received his BBA and MBA degrees from Texas A \& M University-Commerce and his PhD from the University of Arkansas-Fayetteville. His teaching resume includes Texas A \& M University-Commerce, Kilgore College, and the University of Arkansas-Fayetteville before becoming one of the original faculty members at Texas A \& M University-Texarkana in 1972. His areas of teaching include History of Economic Thought, Macroeconomics, Strategic Planning, and Human Resource Management. Dr. Davis is a renowned consultant working through the American Council on Education as a national coordinator and reviewer of corporate and military instructional and training programs. In that role, he has served almost 100 companies and military bases throughout the United States. This year, he received the Distinguished Faculty Award at TAMU-T.

Dr. Joan Brumm is an Accounting Professor in the College of Business at Texas A\&M University-Texarkana. Dr. Brumm received her BS in Accounting from Wayne State University, her MBA from East Texas State University Texarkana, and her Ph.D (Accounting) from Louisiana State University. Dr. Brumm teaches financial accounting and tax. She is the editor of an online peer reviewed journal. Dr. Brumm is a CPA with over 20 years of experience prior to entering academe.

Dr. Ed Bashaw is Dean of the College of Business at Texas A\&M University-Texarkana and Professor of Marketing. Dr. Bashaw received his B.S.E., M.S.E., and M.B.A. degrees from Baylor University and his Ph.D. (Marketing) from the University of Memphis. Dr. Bashaw began his academic career at the University of Arkansas at Little Rock where he was Professor of Marketing and the Director of the Executive MBA program. Dr. Bashaw's primary teaching area revolves around sales/sales management and marketing strategy. Dr. Bashaw has published 17 peer-reviewed journal articles, 22 peer-reviewed conference proceedings/presentations, and won several awards for teaching, research, and service. He currently writes a monthly business column for the Texarkana Gazette. He has consulted with over 40 organizations and individuals during his academic career. Prior to entering academe, Dr. Bashaw held various sales and marketing positions with Fab-Knit Manufacturing and General Mills. 